\title{
KARAKTERISTIK MUTU MARGARIN DENGAN PENAMBAHAN BUBUK ANGKAK SEBAGAI PEWARNA ALAMI
}

\author{
(Quality Characteristics of Margarin With the Addition of Angkak Powder as \\ a Natural Dyes)
}

\author{
Dian Pramana Putra ${ }^{a^{*}}$ dan Rera Aga Salihat ${ }^{a}$ \\ a Universitas Ekasakti \\ * Penulis korespondensi: \\ Email: putra.pramana90@gmail.com
}

\begin{abstract}
Margarine is a semi-solid fat product which is an emulsion with a water in oil (w/o) type, namely the water phase is in the oil phase, with the requirements that it contains not less than 80 percent of the remaining fat is water and additives. This study used cocoa butter and virgin coconut oil (VCO) as a source of fat and oil as raw materials for making margarine. Making margarine uses a blending process, which combines two different melting points of fat and oil so that the melting point is between them. The resulting margarine does not have a color like commercial margarine sold in the market, because there is no added coloring in the manufacturing process. In this study, giving natural color to margarine using Angkak powder, so that the resulting margarine color is reddish. The results showed that margarine with the addition of Angkak powder had no effect on the physical and chemical properties of the resulting margarine. The margarine produced has met the SNI 01-3541-2002 standards.
\end{abstract}

Keywords: quality characteristics, margarine, angkak powder, natural dyes

\begin{abstract}
ABSTRAK
Margarin merupakan produk lemak setengah padat yang merupakan emulsi dengan tipe water in oil (w/o) yaitu fase air berada di dalam fase minyak, dengan persyaratan mengandung tidak kurang 80 persen lemak sisanya adalah air dan bahan aditif. Penelitian ini menggunakan lemak kakao dan minyak Virgin Coconut Oil (VCO) sebagai sumber lemak dan minyak sebagai bahan baku pembuatan margarin. Pembuatan margarin menggunakan proses blending, yaitu menyatukan dua titik leleh lemak dan minyak yang berbeda sehingga titik lelehnya berada diantara keduanya. Margarin yang dihasilkan ini tidak memiliki warna seperti margarin komersil yang dijual dipasaran, karena tidak adanya penambahan pewarna dalam proses pembuatannya. Dalam penelitian ini pemberian warna alami pada margarin menggunakan bubuk angkak, sehingga warna margarin yang dihasilkan berwarna kemerahan. Hasil penelitian menunjukkan margarin dengan penambahan bubuk angkak tidak memberikan pengaruh terhadap sifat fisik dan kimia margarin yang dihasilkan. Margarin yang dihasilkan telah memenuhi standar SNI 01-3541-2002.
\end{abstract}

Kata kunci: karakteristik mutu, margarin, bubuk angkak, pewarna alami

\section{PENDAHULUAN}

Lemak dan minyak merupakan zat makanan yang penting untuk menjaga kesehatan tubuh manusia. Selain itu, lemak dan minyak juga merupakan sumber energi tinggi dibanding karbohidrat dan protein. Minyak atau lemak, khususnya minyak nabati, mengandung asam-asam lemak esensial seperti asam linoleat, lenolenat dan arakidonat yang dapat mencegah penyempitan pembuluh darah akibat 
penumpukan kolesterol serta berfungsi sebagai sumber dan pelarut bagi vitaminvitamin A, D, E, dan K (Winarno, 2004). Margarin merupakan produk lemak setengah padat yang merupakan emulsi dengan tipe water in oil (w/o) yaitu fase air berada di dalam fase minyak, dengan persyaratan mengandung tidak kurang $80 \%$ lemak. Sisanya adalah air (dengan atau tanpa edible protein) dan bahan aditif berupa pengemulsi, pengawet, pewangi dan pewarna, antioksidan serta vitamin (Winarno, 2004; Sahri dan Idris, 2010). Margarin digunakan sebagai pengganti mentega dengan rupa, bau, konsistensi, rasa dan nilai gizi yang hampir sama dengan mentega. Dibidang pangan, penggunaan margarin telah dikenal secara luas terutama dalam baking dan cooking yang bertujuan untuk menambah citarasa bahan pangan (Winarno, 2004).

Sumber lemak setengah padat umumnya adalah lemak hewani, karena lemak hewani memiliki titik cair yang tinggi. Namun, karena lemak hewan mengandung kolesterol yang tidak baik bagi kesehatan serta keberadaan yang terbatas maka perlu dicari sumber alternatif lain. Alternatif yang dapat digunakan adalah minyak nabati karena ketersediaannya yang besar dan murah. Akan tetapi minyak nabati umumnya mempunyai titik cair yang rendah, sehingga diperlukan proses untuk mengubah minyak cair menjadi lemak yang lebih padat. Metode yang biasa digunakan adalah dengan cara hidrogenasi, fraksinasi dan interesterifikasi. Hidrogenasi merupakan cara yang paling banyak digunakan. Hidrogenasi adalah reaksi adisi hidrogen kedalam rantai asam lemak tidak jenuh pada sisi karbon yang mengandung ikatan rangkap. Pada proses ini kemungkinan terjadi isomerisasi, dimana terjadi perubahan konfigurasi dari cis menjadi trans, maka perlu dilakukan penggantian proses hidrogenasi dengan proses lainnya salah satunya proses blending. Salah satu cara untuk menghindari adanya asam lemak trans pada margarin yaitu dengan menggunakan metode interesterifikasi dan pencampuran (bleding) antara minyak berbentuk cair, semi pada dan padat. (Berger dan Idris, 2005)

Proses pencampuran (blending) antara minyak atau lemak yang berbeda harus memiliki titik leleh yang tinggi pada salah satu lemak atau minyak yang akan digunakan. Salah satu lemak yang memiliki titik leleh yang tinggi yaitu lemak kakao. Lemak kakao merupakan lemak dengan karateristik yang spesifik. Dengan demikian, meskipun kandungan oleat tinggi tetapi $80 \%$ dari trigliserida lemak kakao berwujud padat pada suhu ruang dengan titik cair yang tinggi pada 32-35oC (Shukla, 2003).

Margarin yang beredar di pasaran umumnya menggunakan proses hidrogenasi dalam pembuatannya. Sebagaimana diketahui bahwa reaksi hidrogenasi mengubah lemak tidak jenuh menjadi lemak jenuh. Namun, dalam reaksi hidrogenasi ada sebagian kecil asam lemak tidak jenuh mengalami isomerisasi dimana terjadi perubahan konfigurasi dari cis menjadi trans (Kusnandar, 2011). Lemak trans terkenal bersifat radikal bebas dan karsinogenik. Lemak trans yang bersifat radikal bebas, karsinogen, dan adanya timbunan kolesterol dalam darah dapat menjadi faktor utama risiko dan penyebab berbagai jenis penyakit kronis, degeneratif dan kanker yang sekarang sedang mewabah (Sartika, 2008).

Penggunaan metode blending antara lemak atau minyak yang memiliki titik leleh rendah dengan minyak atau lemak yang memiliki titik leleh tinggi akan menghasilkan titik leleh diantara keduanya, sehingga margarin yang dihasilkan akan bersifat semi padat pada suhu ruang. Berdasarkan hasil penelitian Putra (2014) dalam pembuatan margarin dari campuran lemak kakao dan minyak VCO didapatkan margarin dengan penampakan warna yang kurang menarik yaitu kuning pucat, yang berpengaruh terhadap penilaian konsumen dari segi warna. Hasil penelitian Raharjo dan Suprihana (2017), membuat margarin dengan menambahkan ekstrak kunyit dan ekstrak wortel sebagai pewarna alami pada margarin yang berasal dari campuran lemak kakao dan minyak VCO dimana penambahan ekstrak kunyit dan wortel 
mampu meningkatkan warna yang dihasilkan.

Salah satu alternatif pewarna alami yang dapat dijadikan sebagai pewarna pada margarin yaitu angkak. Angkak merupakan beras fermentasi dengan menggunakan ragi Monascus sp. (Andarwulan dan Faradilla, 2012). Pigmen yang dihasilkan ragi ini yaitu warna kuning hingga merah. Pigmen warna dari angkak cenderung lebih stabil, memiliki kelarutan yang tinggi, mudah dicerna dan tidak karsinogenik (Atma, 2015). Penelitian ini bertujuan untuk pengembangan produk pangan dan menghasilkan margarin dengan nilai gizi yang lebih baik dengan penambahan bubuk angkak sebagai sumber antioksidan serta mampu mengendalikan kolesterol darah dengan adanya senyawa statin pada angkak.

\section{BAHAN DAN METODE Waktu dan Tempat}

Penelitian dilaksanakan pada bulan Agustus-September 2020. Penelitian dilaksanakan di Laboratorium Teknologi Hasil Pertanian Universitas Ekasakti dan Laboratorium Mikrobiologi dan Bioteknologi Hasil Pertanian, Laboratorium Instrumentasi Pusat Fakultas Teknologi Pertanian Universitas Andalas Padang.

\section{Bahan dan Alat}

Mikroorganisme yang digunakan yaitu isolat murni Monascus purpureus berumur 21 hari dari koleksi Laboratorium Mikrobiologi dan Bioteknologi Hasil Pertanian Universitas Andalas yang dikultivasi menggunakan Potato Dextrose Agar (PDA) (Merck, Darmstadt,Germany) pada suhu 30-32o C sebelum dimasukan kedalam substrat fermentasi.

Bahan baku yang digunakan pada penelitian ini adalah lemak kakao yang diperoleh dari Pabrik Mini Chokato Kecamatan Payakumbuh Selatan, Sumatera Barat dan minyak VCO yang dibuat berdasarkan metode pembekuan krim santan. Bahan tambahan seperti garam, gum arab, tween 80, pewarna angkak, BHT, vitamin A dan D. Bahan kimia yang digunakan pada penelitian ini adalah Heksan, $\mathrm{NaOH} 0,2 \mathrm{~N}$, alkohol netral 96\%, indikator pp, aquades, indikator pati $1 \%$.

Alat yang digunakan yaitu refrigerator, sentrifus, tabung sentrifus, mixer, corong, kertas saring, wadah plastik, sendok, penangas air, kompor listrik, termometer, dan mortar. Peralatan yang digunakan adalah laminar flow (Telster BV-100 Spain), jarum ose, aluminium foil, timbangan analitik (Kern ABJ 220-4 M), alat gelas (gelas ukur, tabung reaksi, cawan petri, erlenmeyer 250 $\mathrm{ml}$, batang pengaduk dan labu ukur) (Iwaki TE-32 Pyrex, Japan), inkubator (Memmert Model 100-800 INE 600, Germany), hot plate stirrer (AREC Velp Scientifica, Europe), spektofotometer (UV-1800 Shimadzu, Japan), pH meter (Delta OHM HD 2105.2, Italy), kertas saring (Whatchman No 1, China), oven (Philip Haris N3 OC, England), autoclave ( Hiclave HVE-50 Hirayama, Japan), pendingin tegak, sentrifuse (Universal 320 Hettich Germany), Vacuum epavorator (Buchi, Switzerland), Hunter Lab (Color flex EZ 0725, USA), Blender (Philips HR 2115, England), Pipet mikro (Top Petie Dragun Med), Vortex (Velp F 202A0175, Europe), dan Colony Counter (Philip Harris, Englad). texture analyzer (Brook field, Germany) dan alat uji titik leleh (Stuart SMP 30).

\section{Rancangan Penelitian}

Rancangan yang digunakan pada penelitian ini adalah Rancangan Acak Lengkap dengan 5 perlakuan dan 3 ulangan. Data dianalisa secara statistika dengan uji $F$ dan jika berbeda nyata, dilanjutkan dengan uji Duncan's New Multipe Range Test (DNMRT) pada taraf nyata 5\%.

Perlakuan yang dibuat dalam penelitian ini didasarkan pada hasil penelitian Putra, (2014) dengan perbandingan lemak kakao: VCO 70 : 30. Dari hasil penelitian ini akan ditambahakan bubuk angkak sebagai pewarna alami margarin dengan perlakuan sebagai berikut

$$
\begin{aligned}
& A=\text { Penambahan bubuk angkak } 0 \% \\
& B=\text { Penambahan bubuk angkak } 1 \% \\
& C=\text { Penambahan bubuk angkak } 2 \%
\end{aligned}
$$


$\mathrm{D}=$ Penambahan bubuk angkak 3\%

$E=$ Penambahan bubuk angkak 4\%

Persentase penambahan bahan tambahan dalam pembuatan margarin dihitung dari total lemak kakao dan minyak VCO yang digunakan.

\section{Tahapan Penelitian}

Penelitian ini dilaksanakan dalam beberapa tahapan, yaitu penyegaran isolat Monascus purpureus, Fermentasi angkak beras, pembuatan VCO dengan metode pembekuan krim santan, penyediaan lemak kakao dan pembuatan produk Margarin.

\section{Penyegaran dan persiapan kultur kapang Monascus purpureus IPBCC (Asben dan Kasim, 2015) \\ Isolat murni M. purpureus yang diperoleh} dari Institut Pertanian Bogor Culture Collection dikultivasi pada media Potato Dextrose Agar (PDA) steril dengan melarutkan $39 \mathrm{~g}$ PDA kedalam $1000 \mathrm{~mL}$ akuades selanjutnya didihkan dan tuang pada tabung reaksi sebanyak $5 \mathrm{~mL}$ setiap tabungnya lalu disterilisasi dengan autoclave selama 20 menit. Setelah selesai miringkan tabung reaksi dan biarkan media mengeras. Siapkan isolat $M$. purpureus, potong isolat dengan menggunakan jarum ose steril sebesar ujung jarum ose dan letakkan pada media PDA miring. Inkubasi selama 21 hari pada suhu 30 - 32 oC. Kultur berumur 21 hari yang digunakan untuk fermentasi disiapkan. Lepaskan askospora maupun konidia yang ada pada permukaan agar menggunakan lup inokulasi dengan cara memasukkan $5 \mathrm{~mL}$ akuades steril kedalam satu tabung reaksi dan digerus dengan menggunakan jarum ose steril sehingga askospora atau konidia terlepas.

\section{Fermentasi substrat beras (Asben dan Kasim, 2015).}

Erlenmeyer $250 \mathrm{ml}$ steril disiapkan sebanyak 10 buah. Dimasukkan beras yang telah direndam selama 48 jam. Sterilisasi dengan autoclave $1210 \mathrm{C}$ selama 20 menit. Biarkan substrat dingin dalam laminar air flow. Dimasukkan inokulum yang telah dihasilkan sebanyak $10 \%$ dari total substrat. Diaduk-aduk substrat hingga homogen. Kemudian inkubasi pada suhu ruang 28$300 \mathrm{C}$ selama 14 hari. Selanjutnya hasil fermentasi dikeringkan selama 48 jam pada kondisi yang sama (masih dalam erlenmeyer) dan dipindahkan kedalam cawan petri dan dilanjutkan pengeringan selama 48 jam, pada suhu 40-45oC. Hitung kadar air pigmen angkak setelah jadi serbuk hingga kadar air $\pm 7 \%$. Angkak dihaluskan dan disaring menggunakan ayakan ukuran \pm 100 mesh.

Pembuatan VCO dengan Metode Pembekuan Krim Santan (Modifikasi Setiaji dan Prayugo, 2006)

Santan dimasukkan pada wadah dan dibiarkan pada suhu ruang selama \pm 1 jam sehingga terpisah antara skim dan skim. Krim santan dibekukan selama 21-24 jam, kemudian dibiarkan mencair pada suhu ruang. Masukkan masing-masing $30 \mathrm{ml}$ kedalam tabung sentrifus. Putar krim dengan kecepatan 3500 rpm selama 40 menit. Matikan sentrifus dan diamkan 1 menit. Didalam tabung tersebut akan terbentuk tiga endapan yaitu minyak (VCO), blondo dan air. Ambil VCO yang ada didalam tabung dengan pipet secara perlahan-lahan. Saring minyak dengan menggunakan kertas saring whatman. Minyak VCO murni.

\section{Penyediaan Lemak Kakao}

Lemak Kakao diperoleh dari Pabrik Mini Chokato yang terletak di Payakumbuh.Tahapan proses pembuatan lemak kakao berdasarkan cara kerja proses pengolahan kakao di Pabrik Mini Chokato Payakumbuh dengan modifikasi. Pengeringan biji kakao sampai kadar air mencapai 7\%. Sortasi biji kakao dengan menggunakan mesin sortasi yang berkapasitas $2 \mathrm{~kg}$ per 20 menit biji kakao setelah dikeringkan. Penyangraian dengan menggunakan mesin penyangrai tipe batch dengan kapasitas produksi $10 \mathrm{~kg}$ biji kakao tiap 40 menit dengan suhu $\pm 170^{\circ} \mathrm{C}$ sumber 
Vol 20 (2): 111-123, 2021

Tabel 1. Formulasi Margarin

\begin{tabular}{|c|c|c|c|c|c|}
\hline Bahan dasar & Formula A & Formula B & Formula C & Formula D & Formula E \\
\hline Lemak kakao (g) & 70 & 70 & 70 & 70 & 70 \\
\hline Minyak kelapa (g) & 00 & 30 & 30 & 30 & 30 \\
\hline Tween $80^{*}$ & $0,5 \%$ & $0,5 \%$ & $0,5 \%$ & $0,5 \%$ & $0,5 \%$ \\
\hline Gum arab* & $0,5 \%$ & $0,5 \%$ & $0,5 \%$ & $0,5 \%$ & $0,5 \%$ \\
\hline Garam & $1 \%$ & $1 \%$ & $1 \%$ & $1 \%$ & $1 \%$ \\
\hline Angkak* & $1 \%$ & $2 \%$ & $3 \%$ & $4 \%$ & $5 \%$ \\
\hline Air* & $16 \%$ & $16 \%$ & $16 \%$ & $16 \%$ & $16 \%$ \\
\hline Vitamin A & $3.000 \mathrm{IU}$ & $3.000 \mathrm{IU}$ & $3.000 \mathrm{IU}$ & $3.000 \mathrm{IU}$ & $3.000 \mathrm{IU}$ \\
\hline Vitamin D & $260 \mathrm{IU}$ & $260 \mathrm{IU}$ & $260 \mathrm{IU}$ & $260 \mathrm{IU}$ & $260 \mathrm{IU}$ \\
\hline
\end{tabular}

panas yang digunakan berasal dari kayu bakar. Pemisahan dan pemecahan kulit biji. Pemastaan dengan menggunakan mesin pemasta dengan ukuran diameter silinder 10 $\mathrm{cm}$ dan panjang $29 \mathrm{~cm}$. kakao nibs yang dimasukkan sebanyak $0,5 \mathrm{~kg}$ per 15 menit. Pengepresan pasta menggunakan pengempa tipe hidrolik dengan tekanan maksimal 3 bar, dimana diameter piringan pressan $16,3 \mathrm{~cm}$ dan tingginya $4 \mathrm{~cm}$. Output berupa bugkil dan lemak kakao.

\section{Formulasi Pembuatan Margarin (Putra et al., 2014)}

Formulasi yang digunakan dalam pembuatan margarin adalah formulasi dari Putra (2014), terdapat pada Tabel 1.

Pembuatan Margarin (Sarunggalo et. al, 2002 yang dimodifikasi)

Proses pembuatan margarin adalah pencampuran antar fase cair, fase minyak, dan emulsifier dengan perbandingan tertentu sesuai formula yang akan dibuat, sehingga membentuk emulsi W/O. Tahapan dalam pembuatan margarin adalah sebagai berikut : Pencampuran bahan-bahan yang larut lemak atau minyak seperti lemak kakao, minyak VCO, tween 80 , vitamin A dan D sesuai formulasi yang akan diuji. Pencampuran bahan-bahan yang larut air seperti Gum arab, bubuk angkak, dan garam. Pencampuran fase minyak dan fase air. Pengadukan dengan mixer dengan menggunakan kecepatan sedang dan wadah diselimuti air dingin dengan kisaran suhu $17-22^{\circ} \mathrm{C}$ selama 20 menit. Setelah 20 menit maka margarin yang telah jadi dikemas dengan menggunakan wadah cup polipropilen. Dilakukan tempering pada suhu $5-70 C$ selama $2 \times 24$ jam. Proses ini merupakan proses akhir dari pembuatan margarin.

\section{Kadar Air (AOAC, 2005)}

Disiapkan 5 gram contoh margarin dalam wadah aluminium yang sudah diketahui berat totalnya, dicatat berat total wadah beserta isinya, lalu dipanaskan dalam oven bersuhu $105^{\circ} \mathrm{C}$. Setelah satu jam, wadah diambil, dimasukkan desikator hingga dingin, lalu ditimbang hingga diperoleh berat yang konstan.

\section{Penentuan Bilangan Asam (Sudarmadji, 1997)}

Contoh margarin yang diuji ditimbang sebanyak 2 gram di dalam erlenmeyer 250 $\mathrm{ml}$. Kemudian ditambah $50 \mathrm{ml}$ alkohol netral 95\% dan dipanaskan selama 10 menit di atas hot plate sambil diaduk. Larutan ini kemudian dititrasi dengan larutan standar $\mathrm{NaOH} 0,1 \mathrm{~N}$ dan menggunakana indikator phenolpthalein $1 \%$ sampai tepat berwarna merah muda. Selanjutnya, dihitung jumlah miligram $\mathrm{NaOH}$ yang digunakan untuk menetralkan asam lemak dalam gram minyak.Persen asam lemak bebas dinyatakan sebagai oleat pada kebanyakan minyak dan lemak. Asam lemak bebas dinyatakan sabagai \%FFA atau sebagai angka asam.

Kadar Lemak (Metode Soxhlet, AOAC 2005) 
Sebanyak 5 gram contoh margarin diekstraksi dengan pelarut heksana dalam alat Soxhlet selama lebih kurang 6 jam. Ekstraks diuapkan pelarutnyadengan caradistilasikernudian labu yang berisi lemak dipanaskan dalam oven bersuhu $105^{\circ} \mathrm{C}$ hingga diperoleh berat yang tetap.

\section{Bilangan lod (AOAC, 2005)}

Contoh margarin yang diuji ditimbang sebanyak 0,5 gram ke dalam erlenmeyer $250 \mathrm{ml}$ bertutup, kemudian ditambahkan 10 $\mathrm{ml}$ kloroform dan $25 \mathrm{ml}$ pereaksi hanus dan dibiarkan selama 30 menit di dalam ruang gelap, dikocok sekali-kali. Setelah reaksi sempurna ditambahkan $10 \mathrm{ml}$ larutan $\mathrm{KI}$ $15 \%$, ditambahkan $100 \mathrm{ml}$ akuades, dikocok 1 menit dan didiamkan dalam ruang gelap selama 15 menit. Selanjutnya dititrasi dengan natrium tiosulfat $0,1 \mathrm{~N}$ sampai warna kuning hilang, kemudian ditambahkan 0,5 ml indikator pati $1 \%$ dan dititrasi hingga warna biru hilang. Penetapan blanko dengan cara yang sama hanya tidak menggunakan sampel.

\section{Titik Leleh (Melting PointStuart SMP 30)}

Pasanglah termometer pada rangkaian alat. Kemudian masukkan $+1,9$ mm sampel yang telah dihaluskan kedalam pipa kapiler, lalu pasang pipa kapiler. Atur suhu awal pemanasan pada alat $200 \mathrm{C} /$ menit.Jika suhu sudah mendekati suhu bahan meleleh (berdasarkan literatur) naikkan suhu 10C/ menit. Kemudian amati suhu awal bahan meleleh hingga bahan $60 \%$ didalam pipa kapiler meleleh. Kemudian setelah diperoleh waktu meleleh keluarkan pipa kapiler dan turunkan suhu hingga mendekati suhu ruang kemudian baru masukkan sampel lainnya.

\section{Stabilitas Emulsi (Yasumatsu et al., 1972)}

Analisis stabilitas dilakukan untuk mengetahui kestabilan emulsi yang terbentuk antara minyak dan air. Contoh margarin yang telah dipanaskan dalam penangas air bersuhu $80^{\circ} \mathrm{C}$ selama 30 menit diambil $10 \mathrm{ml}$, kemudian disentrifugasi (dengan tabung berskala $10 \mathrm{ml}$ ) dengan kecepatan $2700 \mathrm{rpm}$ selama 10 menit.
Volume campuran yang masih membentuk emulsi diukur dan stabilitas emulsi dihitung.

\section{Daya oles dengan alat Texture analyzer Brook Field (Putra, 2014)}

Pengukuran daya oles dilakukan dengan menggunakan alat Texture analyzer Brook field. Hasil pengukuran kedalaman probe menusuk contoh margarin selama 10 detik berkolerasi langsung dengan kemudahan margarin untuk dioles. Semakin dalam menusuk contoh, maka margarin tersebut akan semakin mudah dioles. Setiap sampel diukur dua kali pengukuran.

\section{Uji warna menggunakan HunterLab (Andarwulan et al., 2014).}

Uji warna ini dilakukan dengan menggunakan alat kolorimeter HunterLab ColorFlex EZ. Alat ini menggunakan keramik putih, dimana sebelum dilakukan uji terlebih dahulu alat ini dikalibrasi. Warna dapat dihitung dengan menggunakan rumus :

$$
\text { Warna }=100-\left(\left(100-L^{*}\right)^{2}+a^{\star 2}+b^{\star 2}\right)^{1 / 2}
$$

Dimana nilai $L^{*}$, $a^{*}$ dan $b^{*}$ dengan kisaran nilai 0 sampai \pm 100 . $L^{*}$ menyatakan parameter kecerahan (Brightness) dengan nilai $L^{*}$ nilai 0 berarti hitam dan 100 putih. Nilai $L^{*}$ menyatakan cahaya pantul yang menghasilkan warna akromatik putih, abuabu dan hitam. $A^{*}$ menyatakan warna kromatik campuran merah - hijau dengan nilai $+a^{*}$ (positif) dari 0 sampai +100 untuk warna merah dan nilai $-a^{*}$ (negative) dari 0 sampai -80 untuk warna hijau. Sedangkan b* menyatakan warna kromatik campuran biru kuning dengan nilai $+b^{*}$ (positif) dari 0 sampai +70 untuk warna kuning dan nilai $-b^{*}$ (negative) dari 0 sampai -70 untuk warna biru.

\section{HASIL DAN PEMBAHASAN}

\section{Pengamatan Bahan Baku}

Berdasarkan Tabel 2 dapat dilihat hasil analisis kimia bahan baku yang digunakan dalam pembuatan margarin. Kadar air pada minyak VCO dan Lemak kakao yang 
Tabel 2. Hasil Analisis Kimia Minyak VCO dan Lemak Kakao

\begin{tabular}{lccccc}
\hline \multirow{2}{*}{ Analisis } & \multirow{2}{*}{ Satuan } & \multicolumn{2}{c}{ Hasil analisis } & \multicolumn{2}{c}{ Standar SNI } \\
\cline { 3 - 6 } & & Minyak VCO & Lemak kakao & Minyak VCO & Lemak kakao \\
\hline Kadar air (b/b) & $\%$ & $0,18 \pm 0,02$ & $0,16 \pm 0,02$ & 0,2 & 0,2 \\
ALB & $\%$ & $0,19 \pm 0,05$ & $1,40 \pm 0,12$ & 0,2 & 1,75 \\
Bilangan lod & lod $/ 100 \mathrm{~g}$ & $3,70 \pm 0,06$ & $25,2 \pm 0,06$ & $4,1-11,0$ & $33-42$ \\
\hline
\end{tabular}

Keterangan : tanda ( \pm ) merupakan nilai standar deviasi.

Tabel 3. Hasil analisis kimia margarin

\begin{tabular}{cccc}
\hline Perlakuan & Kadar air (\%) & Kadar lemak (\%) & ALB (\%) \\
\hline E & $14,29 \pm 0,34$ & $84,23 \pm 0,71$ & $2,33 \pm 0,17$ \\
D & $14,88 \pm 0,15$ & $84,62 \pm 1,24$ & $2,40 \pm 0,20$ \\
C & $14,93 \pm 0,06$ & $84,62 \pm 1,19$ & $2,40 \pm 0,02$ \\
B & $15,09 \pm 0,05$ & $84,90 \pm 0,70$ & $2,46 \pm 0,12$ \\
A & $15,13 \pm 0,12$ & $85,33 \pm 0,76$ & $2,40 \pm 0,20$ \\
\hline KK $=$ & 1,19 & 1,12 & 6,15 \\
\hline
\end{tabular}

Keterangan: tanda ( \pm ) merupakan nilai standar deviasi.

digunakan dalam pembuatan margarin telah memenuhi standar SNI 01-3541-2002 yaitu $0,18 \%$ untuk minyak VCO dan $0,16 \%$ untuk lemak kakao masih dibawah persyaratan lemak dan minyak sebagai bahan pangan maksimal $0,2 \%$. Bahan pangan yang memiliki tingkat kadar air yang rendah dapat disimpan dalam jangka waktu yang lama karena dengan rendahnya kadar air dapat menghambat pertumbuhan mikroorganisme.

Kadar asam lemak bebas VCO yang diperoleh pada penelitian memenuhi standar SNI 7381 (2008) yaitu $0,19 \%$ dimana standar yang disyaratkan adalah maksimal $0,2 \%$. Begitu juga kadar asam lemak bebas yang diperoleh pada lemak kakao memenuhi standar SNI 3748 (2009) yaitu $1,4 \%$ dimana standar yang disyaratkan adalah maksimal $1,75 \%$. VCO dan lemak kakao yang digunakanjuga mengandung kadar air rendah yaitu $0,18 \%$ untuk minyak VCO dan $0,16 \%$ untuk lemak kakao lebih rendah dari yang disyaratkan SNI 0,2\% juga mempengaruhijumlah asam lemak bebas.

Nilai bilangan iod yang diperoleh dari pengujian bahan baku terhadap minyak VCO dan lemak kakao masing-masing $3,7 \mathrm{~g}$ $\mathrm{iod} / 100 \mathrm{~g}$ dan $2,52 \mathrm{~g}$ iod/100 g. Nilai bilangan iod yang diperoleh untuk minyak VCO masih dibawah standar SNI 7381 (2008) yaitu 3,7 g $\mathrm{iod} / 100 \mathrm{~g}$ dimana standar yang disyaratkan adalah maksimal $4,1-11,0 \mathrm{~g}$ iod/100 g, begitu juga dengan nilai bilangan iod untuk lemak kakao masih dibawah standr SNI 3748 (2009) yaitu $25,2 \mathrm{~g}$ iod/100 g dimana standar yang disyaratkan adalah maksimal $33-42 \mathrm{~g}$ $\mathrm{iod} / 100 \mathrm{~g}$.

\section{Kadar air}

Hasil sidik ragam menunjukkan kadar air margarin dengan perlakuan penambahan bubuk angkak tidak berbeda nyata pada taraf nyata $\alpha=5 \%$. Rata-rata kadar air margarin yang dihasilkan dapat dilihat pada Tabel 3. Kadar air margarin yang dihasilkan berkisar 14,29-15,13\%. Kadar air margarin masih memenuhi stnadar SNI 01-35412002. Nilai kadar air yang disyaratkan yaitu maksimal $18 \%$. Kadar air mengalami penurunan dengan meningkatnya penambahan bubuk kakao yang digunakan pada produk margarin. Semakin tinggi jumlah bubuk angkak yang ditambahkan maka semakin rendah kadar air pada margarin. Hal ini karena bubuk angkak yang digunakan dalam pembuatan margarin memiliki kadar air yang rendah yaitu $8,16 \%$.

Air merupakan komponen penting dalam bahan pangan karena kandungan air dalam 
bahan pangan ikut menentukan kesegaran dan daya tahan bahan pangan tersebut (Winarno, 2005). Keberadaan air dalam suatu bahan pangan dapat menyebabkan oksidasi lemak, oleh karena itu perlu dilakukan analisa kadar air. Penetapan kadar air dapat dilakukan dengan beberapa cara. Hal ini tergantung pada sifat bahannya. Berdasarkan hasil penelitian Putra (2014) kadar air margarin berkisar antara $14-15 \%$. Raharjo et al., (2017) melaporkan kadar air margarin yang dihasilkan berkisar antara 9,9 $-11,1 \%$.

\section{Kadar Lemak}

Lemak dan minyak adalah senyawa ester nonpolar yang tidak larut dalam air yang dihasilkan oleh tanaman dan hewan. Lemak dan minyak memiliki fungsi yang penting dalam pengolahan pangan. Karena lemak merupakan ester non polar maka lemak larut dalam pelarut non polar seperti $\mathrm{N}$-heksan, petroleum eter, kloroform dan benzena (Kusnandar, 2011). Hasil sidik ragam menunjukkan kadar lemak margarin dengan perlakuan penambahan bubuk angkak tidak berbeda nyata pada taraf nyata $\alpha=5 \%$. Rata-rata kadar lemak margarin yang dihasilkan dapat dilihat pada Tabel 4.

Kadar lemak margarin yang dihasilkan berkisar 84,23 - 85,33 \%. Kadar lemak produk pada semua perlakuan memenuhi standar SNI 01-3541-2002 yakni kadar lemak yang disyaratkan minimal $80 \%(b / b)$. Margarin merupakan produk lemak setengah padat yang merupakan emulsi dengan tipe water in oil (w/o) yaitu fase air berada di dalam fase minyak, dengan persyaratan mengandung tidak kurang 80 persen lemak. Sisanya adalah air dan bahan aditif berupa pengemulsi, pengawet, pewangi dan pewarna, antioksidan serta vitamin (Winarno, 2005). Kadar lemak yang tinggi pada seluruh perlakuan berasal dari bahan baku yang digunakan yang sebagian besar merupakan lemak dan minyak, dimana lebih dari $80 \%$ bahan baku merupakan lemak dan minyak selebihnya merupakan air dan bahan larut dalam air. Berdasarkan syarat mutu margarin SNI SNI 01-3541-2002 menyatakan margarin harus mengandung lemak minimal $80 \%$ untuk margarin industri, sedangkan margarin krim mengandung lemak berkisar $62-78 \%$, jika jumlah lemak dalam margarin kurang dari jumlah yang di persyaratkan maka kualitas margarin tidak memenuhi syarat SNI (BSN, 2002).

\section{Bilangan Asam}

Hasil sidik ragam menunjukkan bilangan asam margarin dengan perlakuan penambahan bubuk angkak tidak berbeda nyata pada taraf nyata $\alpha=5 \%$. Rata-rata bilangan asam margarin yang dihasilkan dapat dilihat pada Tabel 5. Bilangan asam margarin yang dihasilkan berkisar 2,33 $2,46 \%$. Bilangan asam produk pada semua perlakuan memenuhi standar SNI 01-35412002 yakni bilangan asam yang disyaratkan maksimal 4\% (b/b). Penambahan bubuk angkak tidak berpengaruh terhadap nilai bilangan asam pada margarin.

Bilangan asam menunjukkan banyaknya asam lemak bebas dalam minyak dan dinyatakan dengan $\mathrm{mg}$ basa per 1 gram minyak. Bilangan asam juga merupakan parameter penting dalam penentuan kualitas lemak atau minyak. Bilangan asam menunjukkan banyaknya asam lemak bebas yang ada dalam minyak akibat terjadi reaksi hidrolisis pada minyak terutama pada saat pengolahan. Asam lemakmerupakan struktur kerangka dasar untuk kebanyakan bahan lipid (Ketaren, 2005).

Menurut Kusnandar (2011), keberadaan asam lemak bebas dalam minyak dapat dijadikan indikator awal terjadinya kerusakan karena proses hidrolisis. Reaksi hidrolisis terjadi akibat adanya sejumlah air dalam minyak dan lemak. Dalam reaksi hidrolisis, minyak dan lemak (trigliserida) diubah menjadi asam lemak bebas dan gliserol. Reaksi ini menghasilkan flavour dan bau tengik pada minyak (Ketaren, 2005). 
Tabel 4. Hasil analisis fisik margarin

\begin{tabular}{ccccc}
\hline Perlakuan & Titik leleh $^{\circ} \mathrm{C}$ & Kekerasan (N/cm2) & Stabilitas emulsi (\%) & Warna ( $\left.{ }^{\circ} \mathrm{Hue}\right)$ \\
\hline A & $33,67 \pm 0,14$ & $90,03 \pm 0,06$ & $95,67 \pm 0,58$ & $53,21 \pm 0,24 \mathrm{a}$ \\
B & $33,50 \pm 0,00$ & $91,00 \pm 0,00$ & $96,00 \pm 0,00$ & $47,96 \pm 0,47 \mathrm{~b}$ \\
C & $33,50 \pm 0,14$ & $91,80 \pm 0,03$ & $97,00 \pm 0,00$ & $44,85 \pm 0,06 \mathrm{c}$ \\
D & $33,42 \pm 0,14$ & $91,03 \pm 0,21$ & $96,00 \pm 1,00$ & $38,13 \pm 0,02 \mathrm{~d}$ \\
E & $33,08 \pm 0,14$ & $91,17 \pm 0,06$ & $96,67 \pm 0,06$ & $32,24 \pm 0,05 \mathrm{e}$ \\
\hline KK & 0,33 & 0,18 & 0,60 & 0,73 \\
\hline
\end{tabular}

Keterangan: tanda ( \pm ) merupakan nilai standar deviasi.

Menurut Kusnandar (2011), pembentukan asam lemak bebas akan mempercepat kerusakan oksidatif minyak karena asam lemak bebas lebih mudah teroksidasi jika dibandingkan dengan bentuk esternya. Laju oksidasi dipengaruhi oleh jumlah oksigen yang ada, derajat ketidakjenuhan minyak, adanya antioksidan, adanya proksidan (terutama tembaga) dan beberapa senyawa organik seperti molekul yang mengandung lipoksidase, sifat bahan pengemas, kontak dengan cahaya dan suhu penyimpanan. Pada penelitian ini jumlah bilangan asam pada produk margarin memenuhi sntandar SNI. Nilai bilangan asam sangat rendah karena dalam pembuatan margarin ditambahkan antioksidan yaitu Butil Hidroksi Toulena (BHT). Butylated Hydroxytoluene (BHT) merupakan salah satu zat kimia yang banyak digunakan sebagai antioksidan di dalam makanan kemasan, terutama makanan yang mengandung lemak dan minyak (Yehye et al., 2012).

Antioksidan merupakan salah satu bahan aditif yang dapat menunda atau mencegah terjadinya reaksi oksidasi radikal bebas dalam oksidasi lipid. Selain itu bubuk angkak juga berperan sebagai senyawa antioksidan yang berperan dalam menghambat proses oksidasi. Menurut Chairote, Chairote dan Lumyong (2009), antioksidan dalam angkak terdiri dari beberapa senyawa seperti flavonoid, polifenol, karotenoid, alkaloid, dan vitamin. Beberapa metabolit sekunder yang diproduksi oleh jamur Monascus merupakan komponen yang tersusun atas poliketida.
Komponen tersebut adalah pigmen dan komponen fenolik yang memiliki aktivitas antioksidan.

Titik Leleh (Melting Point Stuart SMP 30)

Titik leleh didefinisikan sebagai temperatur saat sampel dalam pipa kapiler mulai menjadi jernih (Sarungalo et al, 2001). Titik leleh (melting point) merupakan sifat fisik dari asam lemak yang penting. Titik leleh menunjukkan suhu dimana lemak atau minyak berubah wujud dari fase padat menjadi fase cair. Hasil sidik ragam menunjukkan titik leleh margarin dengan perlakuan penambahan bubuk angkak tidak berbeda nyata pada taraf nyata $\alpha=5 \%$. Rata-rata titik leleh margarin yang dihasilkan dapat dilihat pada Tabel 6.

Titik leleh margarin yang dihasilkan berkisar 33,08-33,670C. Titik leleh tertinggi pada perlakuan $A$ dan titik leleh terendah pada perlakuan E. Penurunan titik leleh margarin berbanding lurus dengan peningkatan penambahan jumlah bubuk angkak pada setiap perlakuan. Semakin banyak penambahan bubuk angkak maka titik leleh margarin akan semakin turun, begitu juga sebaliknya. Titik leleh asam lemak akan menentukan titik leleh dan sifat kristalisasi lemak yang disusunnya. Titik leleh asam lemak dipengaruhi oleh panjang rantai karbon, jumlah ikatan rangkap dan konfigurasi cis dan trans. Titik leleh asam lemak akan semakin naik dengan meningkatnya atom karbon yang terikat. Pada jumlah atom karbon yang sama, asam lemak dengan ikatan jenuh lebih tinggi dibandingkan dengan asam lemak tidak 
jenuh. Semakin banyak jumlah ikatan tidak jenuh maka titik leleh akan semakin rendah (Kusnandar,2011). Hasil penelitian Raharjo et al., (2017) melaporkan titik leleh margarin yang dihasilkan berkisar antara $34-36,44^{\circ} \mathrm{C}$.

Titik leleh minyak atau lemak ditentukan oleh ada tidaknya ikatan rangkap asam lemak penyusunnya. Asam lemak jenuh memiliki titik leleh yang lebih tinggi dibandingkan dengan asam lemak tidak jenuh. Titik leleh juga dipengaruhi oleh panjang rantai asam lemak penyusun lemak atau minyak, dimana lemak yang tersusun oleh asam lemak rantai pendek akan memiliki titik leleh yang lebih rendah dibandingkan yang disusun oleh asam lemak rantai panjang (Kusnandar, 2011).

\section{Kekerasan}

Hasil sidik ragam menunjukkan nilai kekerasan margarin dengan perlakuan penambahan bubuk angkak tidak berbeda nyata pada taraf nyata $\alpha=5 \%$. Rata-rata kekerasan margarin yang dihasilkan dapat dilihat pada Tabel 4. Berdasarkan data pada Tabel 6 dapat dilihat bahwa kekerasan margarin yang dihasilkan berkisar antara 90,03-91,17 N/cm2. Nilai kekerasan pada margarin selanjutnya dikatakan sebagai daya oles, kemudahan daya oles tergantung dari komposisi lemak atau minyak yang digunakan. Daya oles tertinggi terdapat pada perlakuan $E$ dengan hasil daya oles 91,17 $\mathrm{N} / \mathrm{cm} 2$ dan daya oles terendah pada perlakuan A dengan hasil daya oles 90,03 $\mathrm{N} / \mathrm{cm} 2$. Penambahan bubuk angkak dalam pembuatan margarin tidak berpengaruh terhadap daya oles margarin yang dihasilkan, semakin tinggi penambahan bubuk angkak maka tekstur dan konsistensi margarin yang dihasilkan sama disetiap perlakuan, sehingga kemampuan jarum probe menusuk margarin akan cenderung sama.

Sarungallo et al., (2001), melaporkan bahwa dengan meningkatnya kandungan lemak padat maka tekstur dan konsistensi margarin menjadi lebih keras dan kaku. Ini akan mempengaruhi kemampuan probe menusuk sampel margarin. Kedalaman probe menusuk sampel margarin selama 10 detik memiliki korelasi langsung dengan kemudahan margarin untuk dioles. Semakin dalam menusuk sampel, maka margarin tersebut akan semakin mudah dioles.

\section{Stabilitas Emulsi}

Kestabilan suatu emulsi merupakan salah satu karakter terpenting dan mempunyai pengaruh besar terhadap mutu produk emulsi Ketika dipasarkan (Suryani et al., 2002). Margarin yang dihasilkan dalam penelitian ini telah memiliki kestabilan emulsi yang cukup baik. Stabilitas emusi margarin dipengaruhi oleh bahan pengemulsi yang dipakai. Dalam penelitian ini menggunakan tween 80 sebagai bahan pengemulsi. Menurut Multiningrum et al., (2009) kestabilan formulasi emulsi dipengaruhi oleh jenis dan konsentrasi pengemulsi. Penggunaan bahan pengemulsi seperti tween 20 dan tween 80 mampu mempertahankan emulsi. Sistem emulsi akan lebih baik jika dilakukan sistem ganda dari pada tunggal, artinya menggunakan bahan tambahan seperti CMC.

Hasil sidik ragam menunjukkan stabilitas emulsi margarin dengan perlakuan penambahan bubuk angkak tidak berbeda nyata pada taraf nyata $\alpha=5 \%$. Rata-rata stabilitas emulsi margarin yang dihasilkan dapat dilihat pada Tabel 4. Stabilitas emulsi margarin yang dihasilkan berkisar 95,67\%96,67\%. Stabilitas emulsi tertinggi terdapat pada perlakuan E (Penambahan angkak 4\%) dan stabilitas emulsi terendah terdapat pada perlakuan A (Tanpa bubuk angkak). Margarin memiliki kestabilan yang cukup baik karena dari hasil pengujian didapatkan stabilitas emulsi lebih dari 85\%. Emulsi yang baik (stabil) tidak akan mengalami pemisahan fase, perubahan warna selama pendiaman ataupun perubahan konsistensi. Stabilitas emulsi yang baik yaitu jika emulsi yang terbentuk antara fase minyak dan fase air $100 \%$.

Kestabilan emulsi antara minyak dan air tidak bergantung pada jenis minyak atau lemak yang digunakan, tetapi dipengaruhi oleh kualitas dari bahan pengemulsi yang digunakan dan proses pengerjaan margarin. Ketidakstabilan emulsi dapat disebabkan 
oleh banyak hal diantaranya tidak sesuainya rasio antar fase minyak dan air, jumlah dan pemilihan emulsifier yang salah, ketidakmurnian di dalam fase air, minyak atau emulsifier, pemanasan yang berlebihan, pembekuan serta waktu dan kecepatan pencampuran yang tidak tepat atau cocok.

Berdasarkan hukum Stokes, kestabilan emulsi akan meningkat jika ukuran partikelnya diperkecil dengan menggunakan alat pencampur homogenizer atau mixer. Menurut Suseno dan Husodo (2000) ketidak stabilan emulsi disebabkan oleh perbandingan jumlah fase terdispersi dan dan pendispersi serta keberadaan zat pengemulsi. Jumlah penambahan lemak yang terlalu banyak, jumlah air yang terlalu sedikit, dan kurangnya zat pengemulsi menyebabkan emulsi menjadi tidak stabil.

Faktor faktor yang mempengaruhi pembentukan emulsi diantaranya, suhu, waktu pengadukan, dan kecepatan pengadukan (Sari dan Lestari,2015). Pada penelitian ini stabilitas emulsi margarin yang dihasilkan masuk kedalam kategori baik. Dalam penelitian ini dilakukan penambahan tween 80 sebagai emulsifier. Penambahan surfaktan komersial (tween 80, dodecyl sulfate, polyoxyethylene sorbitan mono laurat dan dodecyl trimethyl amonium bromide) terhadap stabilitas biji bunga matahri tidak selalu menunjukan penambahan surfaktan dapat meningkatkan stabilitas emusli (Sari dan Lestari, 2015).

\section{Warna}

Hasil sidik ragam menunjukkan nilai warna margarin dengan penambahan bubuk angkak berbeda nyata pada taraf nyata $\alpha=$ $5 \%$. Rata-rata nilai warna margarin yang dihasilkan dapat dilihat pada Tabel 4. Warna margarin dengan penambahan bubuk angkak berkisar antara 32,24 - 53,21 oHue. Nilai warna terendah terdapat pada perlakuan $E$ dengan nilai sebesar 32,24 oHue, sedangkan nilai tertinggi terdapat pada perlakuan A dengan nilai sebesar 53,21 oHue. Semakin rendah nilai oHue maka semakin pekat pula warna yang dihasilkan dan pigmen akan semakin tinggi, begitu juga sebaliknya. Berdasarkan warna margarin yang dihasilkan dapat disimpulkan baha semakin tinggi penambahan bubuk angkak maka semakin merah pula warna margarin yang dihasilkan. Secara visual arna margarin yang dihasilkan merah muda hingga merah sesuai dengan tingkat penambahan bubuk angkak pada pembuatan margarin.

Warna merupakan salah satu factor fisik yang mempengaruhi tingkat kesukaan panelis. Gabungan nilai a yang tinggi dan nilai $b$ yang rendah menghasilkan margarin dengan warna kemerahan sehingga mengahasilkan tingkat kecerahan yang rendah begitu sebaliknya jika nilai a rendah dan nilai $b$ tinggi menunjukkan kecerahan yang tinggi (Rosmisari, 2006).

\section{KESIMPULAN}

Formulasi margarin dapat dilakukan dengan pendekatan sifat fisik dan kimiawi dari produk. Metode yang diunakan dalam pembuatan margarin yaitu pencampuran (blending) antara lemak kakao dan minyak VCO. Bubuk angkak dapat digunakan sebagai pewarna alami dalam pembuatan margarin. Penambahan bubuk angkak tidak memberikan pengaruh terhadap karakterisik mutu margarin yang dihasilkan seperti kadar air, kadar lemak, asam lemak bebas, titik leleh, kekerasan dan satbilitas emulsi tetapi penambahan bubuk angkak memberikan pengaruh nyata pada warna margarin yang dihasilkan. Pada pengujian warna, semakin tinggi penambahan bubuk angkak maka semakin merah pula warna margarin yang dihasilkan. Secara visual warna margarin yang dihasilkan merah muda hingga merah sesuai dengan tingkat penambahan bubuk angkak pada pembuatan margarin.

\section{UCAPAN TERIMA KASIH}

Terimakasih kepada Direktorat Jenderal Pendidikan Tinggi Kementerian Pendidikan, Kebudayaan, Riset dan Teknologi Republik Indonesia yang telah memberikan dukungan 
finansial melalui bantuan Penelitian Dosen Pemula Tahun Anggaran 2020.

\section{DAFTAR PUSTAKA}

Andarwulan, N., Kusnandar, F., Herawati, D., 2014. Pengelolaan Data Analisis Pangan, in: Ananlisis Pangan.

AOAC, 2005. Official Methods of Analysis of AOAC INTERNATIONAL. Off. Methods Ananlysis AOAC Int. 18, 20877-2417.

Asben, A., Kasim, A., 2015. Studi Lama Fermentasi dan Tingkat Kadar Air dalam Produksi Pigmen Angkak pada Substrat Ampas Sagu-Tepung Beras Menggunakan Monascus purpureus. Pros. Semin. Agroindustri dan Lokakarya Nas. FKPT-TPI 185-191.

Atma, Y. 2015. Studi Penggunaan Angkak Sebagai Pewarna Alami Dalam Pengolahan Sosis Daging Sapi. Jurnal Teknologi Universitas Muhammadiyah Jakarta 7(2):76-85.

Badan Standardisasi Nasional, 2009. Lemak kakao. SNI 3748-2009.

Badan Standardisasi Nasional, 2002. Margarin. SNI 3541-2014.

Badan Standarisasi Nasional, 2008. Minyak kelapa virgin (VCO). SNI-7831-2008.

Berger, K. G dan Idris, N. A. 2005. Formulation on Zero Trans Acid Shortenings and Margarins and Other Food Fats With Product of the Oil Palm. Journal Of The Amecican Oil Chemists Society 82(11) 775-780.

Chairote, E.O., G. Chairote., and S. Lumyong. 2009. Red Yeast Rice Prepared From Thai Glutious Rice and Antioxidant Activities. Chiang Mai. J. Sci 36(1) : $42-49$.

Ketaren, S., 2005. Pengantar Teknologi Lemak dan Minyak.

Kusnandar, F. 2011. Kimia Pangan Komponen Mikro.

Murtiningrum, Sarungallo, Z. L., Lisangan, M. M dan Pongsibidang, A. 2009.
Pengaruh Jenis dan Konsntrasi Pengemulsi Terhadap Stabilitas Emulsi Minyak Buah Merah(Pandanus conoideus L). Jurnal Agrotek 1(6):65-71.

Putra, D.P., 2014. Karakteristik Mutu Margarin dengan Pencampuran Lemak Kakao dan Minyak VCO (Virgin Coconut Oil). Skripsi. Universitas Andalas.

Raharjo, S., Sui, M., Suprihana, 2017. Pengaruh penambahan pewarna ekstrak kunyit dan ekstrak wortel terhadap margarin berbahan minyak kelapa dan lemak cokelat. J. Ilmu-ilmu Pertan. AGRIKA 11, 135-145.

Rosmisari, A. 2006. Review: Tepung Jagung Komposit, Pembuatan dan Pengolahannya. Prosiding Seminar Nasional Teknologi Inovatif Pascapanen Pengembangan Pertanian. BPPT. Bogor.

Sahri, M. M dan Idris, N. A. 2010. Palm Stearin as Low Trans Hard Stock For Margarin. Sains Malaysiana 39 (5): 821 827.

Sari, D. K dan Lestari, R. S.D. 2015. Pengaruh Waktu Dan Kecepatan Pengadukan Terhadap Emulsi Minyak Biji Matahari (Helianthus annuus L.) dan Air. Jurnal Integrasi Proses 5(3): 155 159

Sartika, R. A. D. 2008. Pengaruh Asam Lemak Jenuh, Tidak Jenuh dan Asam Lemak Trans terhadap Kesehatan. KESMAS, Jurnal Kesehatan Masyarakat Nasional Vol. 2, No. 4. 154-160.

Sarungallo, Z.L., Soekarto, S.T., Budijanto, S., 2002. Kajian penurunan titik leleh lilin lebah (Apis cerana) dalam pembuatan margarin oles rendah kalori. J. Teknol. dan Ind. Pangan XIII, 157-164.

Setiaji, Bambang., dan Prayugo, Surip. 2006. Membuat VCO Berkualitas Tinggi. Penerbit Penebar Swadaya, Jakarta. 
Shukla, V.K.S., 2003. Chocolate: The Chemistry of Pleasure. INFORM 8.

Sudarmadji, S. 1997. Prosedur analisa bahan makanan dan pertanian, Liberty. Yogyakarta.

Sudarmaji, S.1996. Analisa Bahan Makanan dan Pertanian. Penerbit PAU Pangan dan Gizi. Yogyakarta.

Suryani, A. I. S dan E. Hambali. 2002. Teknologi Emulsi. Jurusan Teknologi Industri Pertanian. Fakultas Teknologi Pertanian. Institut Pertanian Bogor. Bogor.

Suseno, T. I. P dan Husudo, M. M. 2000. Pengaruh Jenis dan Jumlah Lemak yang Ditambahkan Terhadap Sifat Mentega Tempe. Jurnal Teknologi Pangan dan Gizi 1(2): 52-59.
Winarno, F., 2004a. Kimia Pangan dan Gizi. Winarno, F., 2004b. Kimia Pangan dan Gizi. PT. Gramedia Pustaka Utama, Jakarta. Yasumatsu, K., Sawada, K., Moritaka, S., Misaki, M., Toda, J., Wada, T., Ishii, K., 2014. Whipping and Emulsifying Properties of Soybean Products. Agric. Biol. Chem. 36, 719-727. https://doi.org/10.1080/00021369.1972. 10860321.

Yehye, W. A., Rahman, A. N., Alhadi, A., Khaledi, H., Ng, S. W., dan Ariffin, A. 2012. Butylated hydroxytoluene analogs: Synthesis and evaluation of their multipotent antioxidant activities. Molecules, 17(7), 7645-7665. 